University of Nebraska - Lincoln

DigitalCommons@University of Nebraska - Lincoln

Papers in the Earth and Atmospheric Sciences Earth and Atmospheric Sciences, Department

January 2001

\title{
The History of South American Tropical Precipitation for the Past 25,000 Years
}

Paul A. Baker

Duke University, pbaker@duke.edu

Geoffrey O. Seltzer

Syracuse University

Sherilyn C. Fritz

University of Nebraska-Lincoln, sfritz2@unl.edu

Robert B. Dunbar

Stanford University

Matthew J. Grove

Duke University, Division of Earth and Ocean Sciences, Durham, NC

See next page for additional authors

Follow this and additional works at: https://digitalcommons.unl.edu/geosciencefacpub

Part of the Earth Sciences Commons

Baker, Paul A.; Seltzer, Geoffrey O.; Fritz, Sherilyn C.; Dunbar, Robert B.; Grove, Matthew J.; Tapia, Pedro M.; Cross, Scott L.; Rowe, Harold D.; and Broda, James P., "The History of South American Tropical Precipitation for the Past 25,000 Years" (2001). Papers in the Earth and Atmospheric Sciences. 7. https://digitalcommons.unl.edu/geosciencefacpub/7

This Article is brought to you for free and open access by the Earth and Atmospheric Sciences, Department of at DigitalCommons@University of Nebraska - Lincoln. It has been accepted for inclusion in Papers in the Earth and Atmospheric Sciences by an authorized administrator of DigitalCommons@University of Nebraska - Lincoln. 


\section{Authors}

Paul A. Baker, Geoffrey O. Seltzer, Sherilyn C. Fritz, Robert B. Dunbar, Matthew J. Grove, Pedro M. Tapia, Scott L. Cross, Harold D. Rowe, and James P. Broda 


\section{The History of South American Tropical Precipitation for the Past 25,000 Years}

\author{
Paul A. Baker, ${ }^{1 *}$ Geoffrey O. Seltzer, ${ }^{2}$ Sherilyn C. Fritz, ${ }^{3}$ \\ Robert B. Dunbar, ${ }^{4}$ Matthew J. Grove, ${ }^{1}$ Pedro M. Tapia, ${ }^{3}$ \\ Scott L. Cross, ${ }^{1}$ Harold D. Rowe, ${ }^{4}$ James P. Broda ${ }^{5}$
}

\begin{abstract}
Long sediment cores recovered from the deep portions of Lake Titicaca are used to reconstruct the precipitation history of tropical South America for the past 25,000 years. Lake Titicaca was a deep, fresh, and continuously overflowing lake during the last glacial stage, from before 25,000 to 15,000 calibrated years before the present (cal yr B.P.), signifying that during the last glacial maximum (LGM), the Altiplano of Bolivia and Peru and much of the Amazon basin were wetter than today. The LGM in this part of the Andes is dated at 21,000 cal yr B.P., approximately coincident with the global LGM. Maximum aridity and lowest lake level occurred in the early and middle Holocene (8000 to $5500 \mathrm{cal}$ yr B.P.) during a time of low summer insolation. Today, rising levels of Lake Titicaca and wet conditions in Amazonia are correlated with anomalously cold sea-surface temperatures in the northern equatorial Atlantic. Likewise, during the deglacial and Holocene periods, there were several millennial-scale wet phases on the Altiplano and in Amazonia that coincided with anomalously cold periods in the equatorial and high-latitude North Atlantic, such as the Younger Dryas.
\end{abstract}

There are three major centers of deep atmospheric convection: tropical South America, tropical Africa, and the tropical western Pacific

'Duke University, Division of Earth and Ocean Sciences, Durham, NC 27708, USA. ${ }^{2}$ Syracuse University, Department of Earth Sciences, Syracuse, NY 13244, USA. ${ }^{3}$ University of Nebraska, Department of Geosciences, Lincoln, NE 68588, USA. ${ }^{4}$ Stanford University, Department of Geological and Environmental Sciences, Palo Alto, CA 94305, USA. ${ }^{5}$ Woods Hole Oceanographic Institution, Woods Hole, MA 02543, USA.

*To whom correspondence should be addressed. Email: pbaker@geo.duke.edu
(1). These regions play a dominant role in energizing global atmospheric circulation through radiative and latent heating. These regions also introduce important perturbations into an otherwise more zonally uniform atmospheric circulation. Climatic variations in the tropics on interannual and interdecadal time scales affect higher-latitude climate (2) and, in turn, are influenced by higher-latitude climate (3). Because of the short duration of instrumental records and the paucity of proxy records, little is known about either the character or the causes of longer (millennial to orbital) timescale variations in tropical climate and their possible global teleconnections.

Here, we present data from the sedimentary record of Lake Titicaca (Bolivia and Peru) that reveal the nature of climatic variation in tropical South America during the passage from the last glacial stage through the Holocene. We postulate that the ocean-atmosphere interactions that influence modern interannual climatic variability in tropical South America also influenced climatic variability on millennial and orbital time scales.

Lake Titicaca (Fig. 1) is an important climatic archive of the late Quaternary for several reasons. It is the only large and deep freshwater lake in South America, and in deeper portions of the lake, sediment accumulated continuously for at least the past 25,000 years. By contrast, nearly all previously studied sedimentary records in the Amazon basin are lower in temporal resolution throughout and incomplete during the last glacial stage (4). Despite its high altitude ( $3810 \mathrm{~m}$ above sea level) and moderately high latitude (about $16^{\circ}$ to $17.50^{\circ} \mathrm{S}, 68.5^{\circ}$ to $70^{\circ} \mathrm{W}$ ), Lake Titicaca is a reliable recorder of the precipitation that falls on a large portion of tropical South America. The annual cycle and interannual anomalies of precipitation around Lake Titicaca are correlated with those in much of Amazonia south of the equator (5). Also, modern Lake Titicaca is a nearly closed basin lake; thus, its water level, chemical composition, and biota are particularly sensitive to changes in the amount of precipitation.

The sedimentary record of Lake Titicaca has been studied previously by several workers (6-9). Because these earlier studies were conducted on cores taken in water depths $<50 \mathrm{~m}$, and because there was a mid-Holocene lake-level fall of $85 \mathrm{~m}$ (10, 11 ), the previously cored sequences were incomplete. Here, we present findings 


\section{R E P O R T S}

based on analyses of three piston cores and accompanying box cores taken from deeper water sites $(7 \mathrm{PC}$ and $10 \mathrm{BX}, 89 \mathrm{~m}$ water depth; $1 \mathrm{PC}$ and 5BX, $152 \mathrm{~m}$ water depth; 2PC, $230 \mathrm{~m}$ water depth).

We analyzed magnetic susceptibility (MS) on several piston cores; results from 1PC are typical (Fig. 2). Higher values of MS ( $>40$ SI units) characterize the deeper strata; the highest values mark volcanic ash beds or silt beds (thin distal turbidites). The up-core transition to low MS values is due to a transition from detrital-rich sediments to organicrich, detrital-poor sediments. We attribute the cause of this abrupt change to the demise of fluvio-glacial sedimentation as a result of the retreat of mountain glaciers from the position of their LGM advance, which left behind terminal moraines (the lowest of which is at an elevation about $400 \mathrm{~m}$ above the modern lake surface) that dammed outwash rivers and cut off sediment supply to the lake. Thus, the age of the abrupt transition from high to low values of MS yields an age for the end of the LGM in this part of the Andes of 21,000 cal yr B.P. $(12,13)$, which is similar to the age of the LGM in high latitudes.

To constrain the timing and amplitude of lake-level variations, we used several complementary methods including paleobiotic, geochemical, sedimentological, and seismicreflection analyses, as well as information on the formation and demise of paleolakes on the central Altiplano. We used the fraction (relative to the total diatom population) of benthic (shallow-water) diatoms as the most direct method for lake-level reconstruction. The fraction of freshwater planktonic (deepwater) diatoms yields similar information except when the lake exceeds a threshold salinity. Salinity is deduced from the abundance of saline planktonic diatoms. Calcium carbonate $\left(\mathrm{CaCO}_{3}\right)$ content of the sediments is affected both by water depth $\left(\mathrm{CaCO}_{3}\right.$ decreases in deeper water sediments as a result of its increased solubility with the increased pressure, decreased temperature, and increased $\mathrm{P}_{\mathrm{CO}_{2}}$ at greater depths in the lake) and by salinity variations. When lake level drops below the outlet (the Río Desaguadero), salinity builds up in the lake, eventually bringing about the precipitation of $\mathrm{CaCO}_{3}$, increased abundance of saline diatoms, and decreased abundance of freshwater planktonic diatoms. Finally, because the $\delta^{13} \mathrm{C}$ of organic matter in the sediments of Lake Titicaca is largely a mixture of planktonic algae $\left[\delta^{13} \mathrm{C} \approx-25 \%\right.$ PDB (Pee Dee belemnite standard)] and shallowwater macrophytes $\left(\delta^{13} \mathrm{C} \approx-10 \%\right.$ PDB $)$, $\delta^{13} \mathrm{C}_{\text {organic }}$ can be used as an indication of lake level (11), although this signal is complicated by biological variability and diagenetic alteration. In general, we interpret lake-level rise or lake overflow to indicate wet conditions and lake-level fall to indicate dry conditions.
During most of the last glacial stage, including the LGM, Lake Titicaca was deep, fresh, and overflowing. In glacial-age sediments, the fraction of benthic diatoms is low (Fig. 3A) and the fraction of freshwater planktonic diatoms is high (Fig. 3B), $\mathrm{CaCO}_{3}$ (Fig. 3C) and saline planktonic diatoms (Fig. 3D) are absent, and $\delta^{13} \mathrm{C}_{\text {organic }}$ (Fig. 3E) remains less than $-23 \%$ (the modern value in the presently overflowing lake). The presence of a large paleolake "Tauca" on the central Altiplano also indicates that Lake Titicaca continuously overflowed to the south between 26,000 and 15,000 cal yr B.P. (14).

A dry period between about 15,000 and
13,000 cal yr B.P., coinciding with the Bølling-Allerød warm period of the highlatitude North Atlantic region, is marked in Lake Titicaca by a small increase in benthic diatoms (Fig. 3A) and a decrease in freshwater planktonic diatoms (Fig. 3B). The onset of deposition of salt in the Salar de Uyuni and fluvial sediments on its margins marked the demise of paleolake Tauca around 15,000 cal yr B.P. (14-16), indicating that Lake Titicaca had dropped below its outlet level, hence, it no longer fed the paleolake.

Lake Titicaca overflowed again and a paleolake occupied the central Altiplano (14) between 13,000 and 11,500 cal yr B.P., co-
Fig. 1. Lake Titicaca is located in the northern portion of the Altiplano, a high-elevation, internally-drained plateau situated between the eastern and western cordilleras of the tropical Andes. The lake consists of two nearly separate subbasins, Lago Grande (7131 km², $125 \mathrm{~m}$ average depth) and Lago Huiñaimarca (1428 km², $9 \mathrm{~m}$ average depth). The subbasins are connected by the shallow ( 25 $m$ depth) Strait of Tiquina. The lake periodically discharges (depending on lake level) southward via the Río Desaguadero into the large, shallow, saline Lago Poopo, and, in the wettest times, into the presently dry Salars (salt flats) of Coipasa and Uyuni.

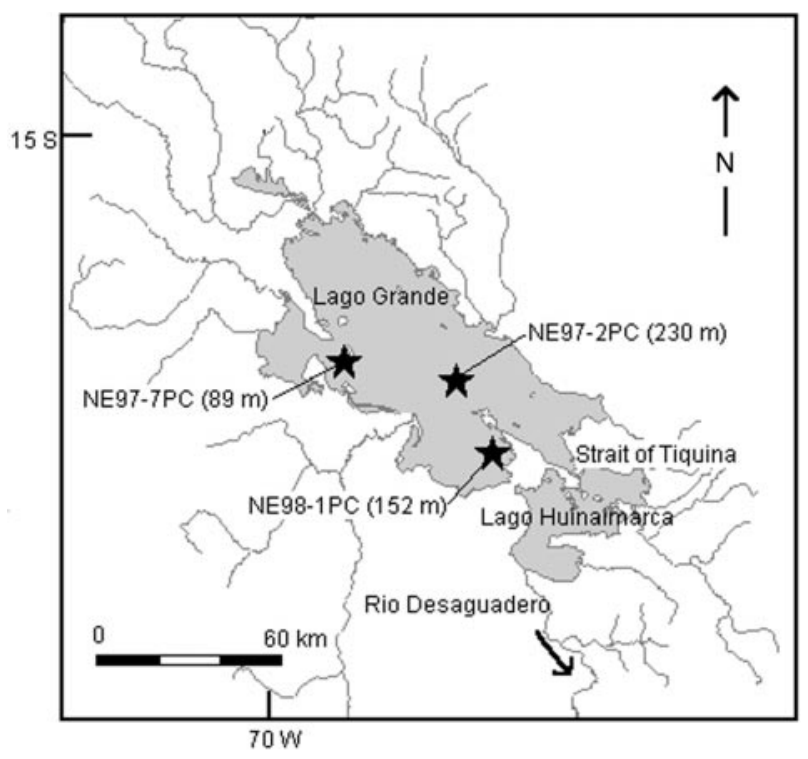

Fig. 2. Magnetic susceptibility (MS, black points and line) of 1PC increases with increased detrital content of the sediments, thus fluvioglacial sediments below $450 \mathrm{~cm}$ have high values of MS. The dramatic decreases in MS and sedimentation rate at this level are ascribed to glacial retreat, hence are coincident with the last glacial maximum in this part of the Andes. A prominent volcanic ash at $885 \mathrm{~cm}$ has been observed in cores and seismic records throughout much of the lake and is dated at 27,500 cal yr B.P. Age dating (gray points and dashed line) on 1PC was done by accelerator

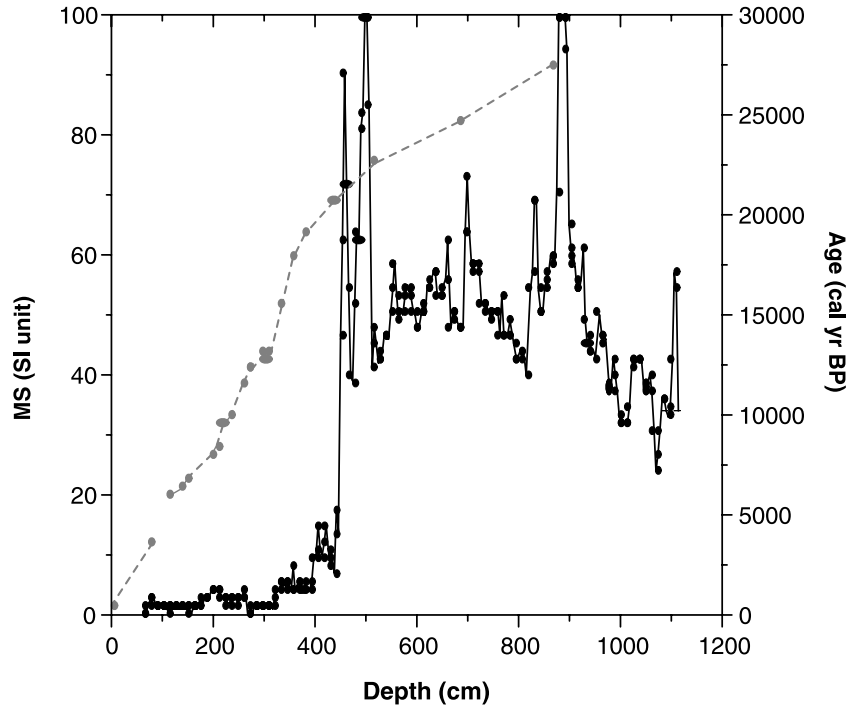

mass spectrometry ${ }^{14} \mathrm{C}$ analysis of carbon derived from acid-leached, bulk sediment samples. Dates were calibrated using (36) for samples younger than 24,000 cal yr B.P. and (37) for older samples (all dates in the text and figures are presented as calibrated years before 1950 AD). No correction for reservoir effect was applied: a modern reservoir effect of 250 years has been reported for Lago Huiñaimarca (7), but Lago Grande surface sediment samples from our box cores show zero reservoir effect. The age models for the cores were based on simple interpolation between samples. Age models were constructed in the same manner for 2PC (11 dates) and 7PC/10BX (14 dates). 


\section{R E P O R T S}

inciding with the Younger Dryas cold period of the North Atlantic region. Increased wetness was marked in Lake Titicaca by a minimum of benthic diatom abundance and a maximum of freshwater planktonic diatoms.

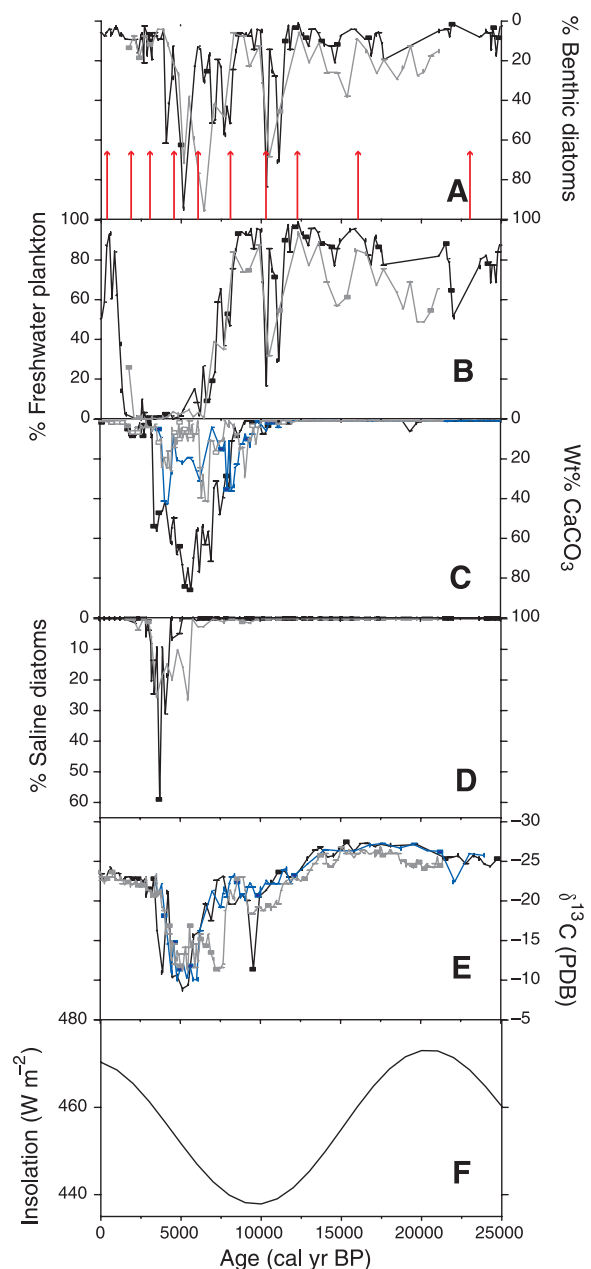

Fig. 3. Chemical, isotopic, and biotic analyses of sediments from Lake Titicaca. All proxies are plotted in the same sense: up generally signifies higher lake level or fresher water. Black line and dots are from core $1 \mathrm{PC}$, gray line and dots are from 7PC, and blue line and dots are from 2PC. (A) Relative abundance of benthic diatoms. Benthic diatom abundance includes Pseudostaurosira zeilleri and a diverse array of other attached taxa. Core 1PC is in bold black because this curve is used as our most reliable indicator of lake level. Red arrows are centered on North Atlantic cold events $(26,29)$. (B) Relative abundance of freshwater planktonic diatoms. The freshwater planktonic diatoms in the Lake Titicaca sediments are primarily $\mathrm{Cy}$ clotella andina, Cyclotella stelligera, Aulacoseira granulata, and Fragilaria crotonensis. (C) Weight percent (Wt\%) $\mathrm{CaCO}_{3}$. (D) Relative abundance of saline diatoms. The curve for saline planktonic diatoms represents the abundance of Chaetoceros muelleri. (E) Carbon isotopic composition of sedimentary total organic carbon. (F) Calculated January insolation at $15^{\circ} \mathrm{S}(32)$. High values at the LGM and today correspond to periods of enhanced summer convection in tropical South America.
A rapid and large-amplitude drop in the level of Lake Titicaca commenced at about $11,500 \mathrm{cal}$ yr B.P. This change is marked by replacement of freshwater planktonic diatoms by benthic taxa. Levels of $\delta^{13} \mathrm{C}_{\text {organic }}$ increased above $-23 \%$ for the first time in the record, indicating that Lake Titicaca fell below its outlet. As a result, salinity began to increase in the lake as further evidenced by small, but significant, amounts of $\mathrm{CaCO}_{3}$ in the sediments of this interval. This dry phase lasted until about 10,000 cal yr B.P.

The lake again rose to overflow level between 10,000 and 8500 cal yr B.P. Freshwater planktonic diatoms became dominant, $\mathrm{CaCO}_{3}$ decreased, and $\delta^{13} \mathrm{C}_{\text {organic }}$ decreased to overflow values. By 8500 cal yr B.P., lake level fell sharply as the Altiplano again became dry. This desiccation is recorded by all of our proxy measurements. A reversal of the drying trend took place between 7000 and 6000 cal yr B.P., producing a decrease in benthic diatoms in core 1PC. This was followed by an extremely dry period between 6000 and 5000 cal yr B.P., when Lake Titicaca fell to its lowest level of the past 25,000 years, most likely producing the low-stand features identified seismically at $85 \mathrm{~m}$ below present-day lake level (10).

Increasing lake level beginning at about $4500 \mathrm{cal}$ yr B.P. is indicated by decreases in benthic diatoms, $\mathrm{CaCO}_{3}$, and $\delta^{13} \mathrm{C}_{\text {organic }}$. This wet phase is confirmed by the presence of a small lake that occupied the Río Desaguadero valley continuously between 4600 and $3900 \mathrm{cal}$ yr B.P. (17). Lake Titicaca rose to within $25 \mathrm{~m}$ of its modern average level and flooded southward through the Strait of Tiquina, filling the Lago Huiñaimarca subbasin at $3500 \mathrm{cal}$ yr B.P. (7).

A detailed lake-level curve for Lake Titicaca for the past 3500 calibrated years has previously been determined from several shallow-water cores raised from Lago Huiñaimarca (7). Rising or overflowing water levels in Lago Huiñaimarca were indicated during the periods approximately from $>3500$ to 3200,2800 to 2500,2200 to 2000 , and 500 to 0 cal yr B.P. Lago Huiñaimarca never completely desiccated in the late Holocene, and thus, the water level in the deep basin of Lake Titicaca remained high throughout this period. In our cores, $\mathrm{CaCO}_{3}$ disappears completely and freshwater planktonic diatoms rise rapidly by about $2000 \mathrm{cal}$ yr B.P., signifying the freshening (via outflow) of Lake Titicaca to modern values by that time. The existence of a paleolake at 2000 cal yr B.P. in the Río Desaguadero valley just south of the modern outlet implies that the Altiplano was particularly wet and Lake Titicaca was a few meters above its modern level at that time (17).

Our most important new findings from the core data are the existence of high or rising lake levels during the entire LGM, the Younger Dryas chronozone, and the Holocene "Bond" events. Here, we address the significance of these findings in a regional context, and we address possible larger-scale teleconnections.

Precipitation has been measured at many stations on the Altiplano, but most time series are short, incomplete, and sometimes inaccurate. The longest continuous meteorological time series on the Altiplano is the lake level of Lake Titicaca, measured at Puno, Peru, since 1915 by the Servicio Nacional de Meteorologia y Hydrologia de Peru. Because precipitation on the northern Altiplano is highly correlated with lake-level rise, we can use Lake Titicaca as a basin-wide rain gauge (18). The average wet season (October to March) increase in lake level is $0.51 \pm$ $0.40 \mathrm{~m}$, whereas the average dry season fall of lake level is $0.51 \pm 0.16 \mathrm{~m}$; the greater variance of wet-season lake-level rise demonstrates that the variability of precipitation is much greater than the variability of evaporation. This observation supports our use of lake-level change as a measure of precipitation amount. On longer time scales, this contention is supported by modeling studies of the Lake Titicaca water budget (19). Furthermore, the oxygen isotopic composition of the Quelccaya ice cap (20), located just north of the Lake Titicaca watershed, is also highly correlated with lake-level change: more negative values of $\delta^{18} \mathrm{O}$ in an annual layer of ice occur in wetter years (18). Thus, reconstruction of lake level (or analysis of $\delta^{18} \mathrm{O}$ in ice cores) allows us to reconstruct the history of precipitation on the Altiplano. But, can we generalize the precipitation history of the Altiplano to the Amazon?

Atmospheric variability of the tropics is strongly modulated by sea-surface temperature (SST) (21), and many studies have discussed the nature and controls on SST variability in the tropical Atlantic $(22,23)$. For instance, it was demonstrated $(24,25)$ that the meridional SST gradient in the equatorial Atlantic directly affects rainfall amount in the Nordeste region of Brazil. Nobre and Shukla (5) showed that the droughts of the Nordeste are part of a larger regional impact of SST variability on rainfall and that precipitation anomalies in the southern Nordeste region (approximately $10^{\circ}$ to $15^{\circ} \mathrm{S}, 40^{\circ}$ to $50^{\circ} \mathrm{W}$ ) are out of phase with anomalies in northern Nordeste and much of the Amazon (approximately $0^{\circ}$ to $10^{\circ} \mathrm{S}, 35^{\circ}$ to $70^{\circ} \mathrm{W}$ ). The Amazon generally has higher rainfall (and the southern Nordeste region has lower rainfall) in years when the northern equatorial Atlantic has anomalously low SST. We can extend this spatial correlation by noting that annual rise of Lake Titicaca is also inversely correlated with northern equatorial Atlantic SST $[r=-0.324, n=75$, significant at the $99 \%$ 


\section{R E P O R T S}

confidence level, also earlier noted by (18)]. Lake-level rise was significantly higher in 8 of the 11 years of low SST used by Nobre and Shukla (5), and was lower in 7 of 10 years of high SST. We conclude that our reconstructions of rising or overflowing levels of Lake Titicaca can be used to deduce the timing of wet conditions on the Altiplano and in Amazonia. Also, wet conditions in both regions are promoted by below-normal SST in the northern equatorial Atlantic.

Do modern controls on precipitation variability apply to the past? Melice and Roucou (18) showed that a 12- to 14-year periodicity of the $\delta^{18} \mathrm{O}_{\text {ice }}$ signal persisted throughout the past 500 years of the Quelccaya record (20) and was correlated with SST variability in the tropical North Atlantic. Their findings imply that for the past 500 years there has been a persistent, quasi-periodic fluctuation of tropical Atlantic SST that influenced precipitation variability on the Altiplano and in Amazonia.

On longer time scales, millennial-scale cold events observed in North Atlantic SST records (26) during the last glacial stage were manifested as wet events in tropical South America (14). Anomalously low equatorial North Atlantic SSTs during the LGM (27), the Younger Dryas (26), or during Holocene cold events $(28,29)$ such as the Little Ice Age, were as much as 20 times the magnitude of the largest modern interannual SST anomalies (around $0.5^{\circ} \mathrm{C}$ ), so the potential SST forcing of atmospheric variability during such events was far stronger than during the past century of direct measurement. We assert that this large variability of equatorial North Atlantic SST exerted a strong control on the variability of precipitation on the Altiplano and in Amazonia, on millennial and orbital time scales.

DeMenocal and co-workers (29) established that Holocene-age cold events of the high-latitude North Atlantic Ocean (28) were in phase with SST decreases, enhanced upwelling, and increased accumulation of Saharan dust, in the eastern equatorial North Atlantic. These events appear to correspond to periods of rising or overflowing level of Lake Titicaca (Fig. 3A), allowing for the possible need for a reservoir correction of about 250 years for our middle Holocene radiocarbon dates.

With few exceptions $(30,31)$, researchers have previously concluded that Amazonia was arid during the LGM, so our finding of a wetter-than-modern Altiplano and Amazonia during the LGM warrants explanation. There are three physical explanations for LGM wetness in Amazonia. First, wet season insolation was at a maximum in the southern tropics at 20,000 cal yr B.P. (Fig. 3F) (14, 32); thus, the South American summer "monsoon" (33) was maximized [and early Holocene insolation and precipitation were mini- mal, exactly out of phase with the northern tropics $(29,34)]$. Second, during the LGM, zonal [cold in the east (26), warm in the west (35)] and meridional [cold in the north, warm in the south (27)] SST gradients in the equatorial Atlantic were favorable for enhanced SST forcing of the northeast trades and atmospheric advection of water vapor into Amazonia (14). Third, lower equatorial Atlantic SST favored increased gradients between land and sea-surface temperature during the austral summer, also enhancing water vapor transport into Amazonia.

\section{References and Notes}

1. P. J. Webster, in Large-Scale Dynamical Processes in the Atmosphere, B. J. Hoskins, R. Pearce, Eds. (Academic Press, New York, 1983), pp. 235-275.

2. B. Rajagapolan, Y. Kushnir, Y. Tourre, Geophys. Res. Lett. 25, 3967 (1998)

3. S.-P. Xie, Y. Tanimoto, Geophys. Res. Lett. 25, 2185 (1998).

4. M. P. Ledru, J. Bertaux, A. Sifeddine, K. Suguio, Quat. Res. 49, 233 (1998).

5. P. Nobre, J. Shukla, J. Clim. 9, 2464 (1996).

6. D. Wirrmann, L. F. Oliveira Almeida, Palaeogeogr. Palaeoclimatol. Palaeoecol. 59, 315 (1987).

7. M. Abbott, M. Binford, M. W. Brenner, K. R. Kelts, Quat. Res. 47, 169 (1997).

8. P. Mourguiart et al., Palaeogeogr. Palaeoclimatol. Palaeoecol. 143, 51 (1998).

9. J. Argollo, P. Mourguiart, Quat. Int. 72, 37 (2000)

10. G. O. Seltzer, S. Cross, P. Baker, R. Dunbar, S. Fritz, Geology 26, 167 (1998).

11. S. L. Cross, P. A. Baker, G. O. Seltzer, S. C. Fritz, R. B. Dunbar, Holocene 10, 21 (2000).

12. J. H. Mercer, in Late Cainozoic Paleoclimates of the Southern Hemisphere, J. C. Vogel, Ed. (Balkema, Rotterdam, 1984), pp. 45-58.

13. G. O. Seltzer, J. Quat. Sci. 7, 87 (1992).
14. P. Baker et al., Nature, in press

15. M. Servant et al., C. R. Acad. Sci. Paris Ser. Ila 320, 729 (1995).

16. F. Sylvestre et al., Quat. Res. 51, 54 (1999).

17. P. Baucom, C. Rigsby, J. Sediment. Res. 69, 597 (1999).

18. J. Melice, P. Roucou, Clim. Dyn. 14, 117 (1998)

19. S. L. Cross, P. A. Baker, G. O. Seltzer, S. C. Fritz, R. B. Dunbar, Quat. Res., in press.

20. L. G. Thompson, E. Mosley-Thompson, W. Daansbarg, P. Grootes, Science 234, 361 (1986).

21. R. Sutton, S. P. Jewson, D. P. Rowell, J. Clim. 13, 3261 (2000).

22. P. Chang, L. Ji, H. Li, Nature 385, 516 (1997).

23. D. Enfield, D. Mayer, J. Geophys. Res. 102, 929 (1997).

24. S. Hastenrath, L. Heller, Q. J. R. Meteorol. Soc. 110, 77 (1977).

25. S. Hastenrath, J. Atmos. Sci. 35, 2222 (1978).

26. E. Bard, R. Rostek, J.-L. Turon, S. Gendreau, Science 289, 1321 (2000).

27. A. C. Mix, A. E. Morey, N. G. Pisias, S. W. Hostetler Paleoceanography 14, 350 (1999).

28. G. Bond et al., Science 278, 1257 (1997).

29. P. deMenocal, J. Ortiz, T. Guilderson, M. Sarnthein, Science 288, 2198 (2000).

30. P. A. Collinvaux, P. E. De Oliveira, M. B. Bush, Quat. Sci. Rev. 19 (2000).

31. S. Haberle, M. Maslin, Quat. Res. 51, 27 (1999)

32. A. Berger, P. J. Loutre, Quat. Sci. Rev. 10, 297 (1991).

33. J. Zhou, K.-M. Lau, J. Clim. 11, 1020 (1998).

34. J. C. Curtis, D. A. Hodell, in Climate Change in Continental Isotopic Records, P. K. Swart, K. C. Lohmann, J. McLenzie, S. Savin, Eds. (American Geophysical Union, Washington, DC, 1993), pp. 135-152.

35. C. Rühlemann, S. Mulltza, P. Müller, G. Wefer, R. Zahn, Nature 402, 511 (1999).

36. M. Stuiver et al., Radiocarbon 40, 1041 (1998).

37. E. Bard, Geochim. Cosmochim. Acta 62, 2025 (1998).

38. Supported by NSF grants to P.A.B., G.O.S., S.C.F., and R.B.D. The cooperation of M. Revollo, J. Sanjines, and Autoridade del Lago Titicaca, Bolivia/Peru, is gratefully acknowledged.

3 July 2000; accepted 13 December 2000 